\title{
Biological identification of Mycoplasma gallisepticum causing respiratory problems in layer flocks in Quetta district of Balochistan
}

Muhammad Adnan Atique*, Ferhat Abbas, Muhammad Masood Tariq, Shakeel Babar, Muhammad Arif Awan, Irshad Ali and Farhat Abbas Bokhari

Center for Advanced Studies in Vaccinology and Biotechnology, University of Balochistan, Quetta,-Pakistan

*Corresponding author's email: adnancasvab@yahoo.com

Citations

Muhammad Adnan Atique, Ferhat Abbas, Muhammad Masood Tariq, Shakeel Babar, Muhammad Arif Awan Irshad Ali and Farhat Abbas Bokhari. Biological identification of Mycoplasma gallisepticum causing respiratory problems in layer flocks in Quetta district of Balochistan. Pure and Applied Biology. Vol. 6, Issue 4, pp1487-1493. http://dx.doi.org/10.19045/bspab.2017.600160

Received: 02/11/2017 $\quad$ Revised: 04/12/2017 $\quad$ Accepted: 05/12/2017 $\quad$ Online First: 06/12/2017

\section{Abstract}

Mycoplasma is of countless fear in avian mycoplasmosis. Their popularity in salable fowl is influencing reasonable victims in Pakistan. The breathing ailment in Balochistan in layer flocks is affecting frugally massive damages. This manuscript describes the serological and polymerase chain reaction established incident of Mycoplasma gallisepticum. Mycoplasmas gallisepticum is branded for affecting respirational illness in layers. The antibodies existence of Mycoplasma gallisepticum is testified here in sera trials $(\mathrm{N}=720)$ in 60 farms with breathing indications in Quetta district, Pakistan. Blood samples were confirmed for Mycoplasma gallisepticum antibody/antigen presence by serum plate agglutination and by enzyme-linked immunosorbant assay. In layer flocks, the Mycoplasma gallisepticum antibodies detected by plate agglutination test and enzyme linked immunosorbant assay were $21 \%$ and $35 \%$ respectively. The lung tissue samples were processed for isolation of Mycoplasma gallisepticum by culturing in Pleuropneumonia like organism broth and agar and DNA was extracted from cultures by Puregene Gentra kit. Field cultures from lung tissue samples $(\mathrm{N}=1112)$ were analysed to identify the Mycoplasma gallisepticum occurrence was $19 \%$ yielded a PCR product of $730 \mathrm{bp}$. An early diagnosis of disease caused by Mycoplasma gallisepticum the serum plate agglutination, enzyme linked immunosorbent assay are helpful and diagnosis should be further confirmed by polymerase chain reaction.

Keywords: Mycoplasma gallisepticum; Layers; SPA; ELISA; PCR; Quetta

Introduction

Amid the numerous avian Mycoplasmas, merely Mycoplasma gallisepticum is affecting reasonable injuries to the poultry trade [1]. In layers Mycoplasma gallisepticum is the core root of causing respiratory symptoms even in chickens, turkeys, pigeons and several other game 
birds [2]. The Mycoplasma gallisepticum can be basis of chronic respiratory disease (CRD) subsequent into shrank progress or egg production in layers [3]. Noticeable evils might contain rales, coughing, and sneezing, nasal ejections and may obvious bulge around eyes [4]. Mycoplasma gallisepticum is transmitted vertically through infected eggs and blow-out horizontally from one fowl to another $[5,6]$.

The Mycoplasma gallisepticum is considered as contagious infection established by analysis of DNA findings and serum antibodies detection. Existence of Mycoplasma gallisepticum can be longestablished by leading serological documentation through serum plate agglutination (SPA) and ELISA [3]. Now, it is conveyed that existence together of Mycoplasma synoviae and Mycoplasma gallisepticum are in a solo situation of turkey. PCR is stress-free and more specific tool for judgment of avian mycoplasmosis [7]. PCR is an easy, simple more sensitive instrument for diagnosis of avian mycoplasmosis [8]. One researcher earlier supported and further advocated that Mycoplasma synoviae and Mycoplasma gallisepticum is the relevant mediator of pneumonic fowl lungs [9].

In Pakistan, clinically the respiratory problems are complications and significantly dominant and finished excessive intimidations to the poultry flocks but in opinion of very squat evidence accessible concerning precise incidence of the ailments in the realm [10]. There is a necessity to identify and decide Mycoplasma gallisepticum contagions between those breathing ailments. In Quetta no earlier information or documents on occurrence of avian mycoplasmosis has been available.

Serological documentation is a useful for a prompt judgment of chronic respiratory disease initiated by Mycoplasma gallisepticum to map an antibiotic cure to hamper the ailment. An optimistic serological check laterally in the midst of account as well as cryptograms characteristic of the chronic respiratory disease, compose of guess of preliminary verdict, is a upcoming prospect on the separation and detection of the bag should be done [11]. The Mycoplasma gallisepticum alleged flock is recognized by serum-plate agglutination (SPA) check and advance established via ELISA [3]. Serological recognition of Mycoplasma gallisepticum antibodies with (SPA) is a preliminary and rapid process [12]. The verdict by (SPA) checks can advance be definite by ELISA [13]. SPA is employed as the screening test because it is rapid, highly sensitive but less specific and is inexpensive. While as an ELISA has been reported more sensitive and specific than SPA test [14]. Polymerase chain reaction (PCR) of DNA in a straight line obtains from Mycoplasma gallisepticum polluted tissue or wipe is the top molecular device for the finding \& description of Mycoplasma gallisepticum-chronic respiratory ailment. The DNA taking out and utilize of (PCR) are the finest well-known molecular practice for rapid detection and verdict of Mycoplasmosis [15]. Nascimento et al. [8] used Mycoplasma gallisepticum specific primers for recognition of Mycoplasma gallisepticum in culture. This Mycoplasma gallisepticum exact PCR was carried out on broth culture and model in traditional bacteriological handling [16]. Mycoplasma gallisepticum targeted genes are the $\mathrm{mgcl}$, mgc2, GapA and PvpA genes for GTS (gene targeting sequencing technique) for Mycoplasma gallesepticum illness judgment [17]. In a study $16 \mathrm{~S}$ rRNA specific primers were used to amply the Mycoplasma [16]. A PCR was developed basically for finding of Mycoplasma gallisepticum [18] and was repeated worldwide for finding of mycoplasmosis in specific DNA 
magnification [18, 19]. Used a (PCR) kit to sense Mycoplasma gallisepticum illness in trial of tracheal and lung swabs of broiler and layer flocks. DNA was take out and enlarged, using a simple PCR. The prevalence of Mycoplasma gallisepticum was highest in the layer flocks, at 33.3\% [20]. Mycoplasma gallisepticum nested PCR for diagnosis of Mycoplasma gallisepticum infection just targeting the GapA gene. The PCR assay indicated (26\%) positive flocks with Mycoplasma gallisepticum (MG) and PCR proved to be useful method for an early diagnosis of MG outbreaks in Pakistan [21].

\section{Materials and methods}

This study was carried out after receiving complaints from poultry farmers reporting the respiratory symptoms in their layers. From suspected layers aged 24 weeks the blood samples were taken, from which serum was separated for serological examination. For this purpose, a sum of sixty flocks $(60 \times 12)$ was sampled. Blood samples $(n=720)$ were taken, representing twelve birds from 60 suspected flocks for the occurrence of MG antibodies. Serum from blood models $(\mathrm{n}=720)$ was separated for Mycoplasma gallisepticum serological check. All of these flocks under study were free of any Mycoplasma vaccination history. The blood samples were processed in the Centre for Advanced Studies in Vaccinology and Biotechnology (CASVAB), University of Baluchistan for serum analysis.

\section{Serum plate agglutination}

Layer flocks were monitored by serum plate agglutination (SPA) test. An equal amount of serum was mixed with $0.03 \mathrm{ml}$ of Mycoplasma gallisepticum antigen. Clumping was observed within 1 minute.

\section{ELISA test}

ELISA kit (Synbiotics Corporation, ProFlock, USA) was used for identification of MG antibodies as the provided directions. Readings (optical density) were taken by setting an IDEX (BDSL Immunoskan,
England) micro plate reader at $405 \mathrm{~nm}$ wave length. Optical density values $\geq 0.6$ were positive while all $\leq 0.6$ had no Mycoplasma gallisepticum antigen/antibody.

\section{DNA extraction from mycoplasma cultures}

Frey's pleuropneumonia look organism (PPLO) liquid and solid media was prepared for the classical bacterial processing and culturing of the Mycoplasma [6, 22]. Lung tissue samples $(n=1560)$ were gathered from 20 different commercial broiler flocks in Quetta $(n=8)$, Kucklak $(n=6)$ and Pishin $(\mathrm{n}=6)$ area of Quetta, Pakistan representing 840,360 and 360 birds respectively from each flock for the detection of Mycoplasma. Out of 1560 broiler lung tissue samples 1112 cultures (72\%) were sensitive to $1.5 \%$ digitonin for Mycoplasma species producing growth inhibition zone. Digitonin sensitive triple cloned cultures were subjected for DNA extraction. DNA was extracted from mycoplasma cultures by following DNA Purification Kit PUREGENE (Gentra, USA) instructions.

\section{Polymerase chain reaction $(\mathrm{PCR})$}

In this study primers which amplify 16s rRNA gene were used to recognize Mycoplasma gallisepticum from cultures isolated from layers lung tissue samples. The reaction mixture was prepared in a laminar flow cabinet. For 50 $\mu 1$ PCR reaction the mixture was as under. Briefly, the PCR mix was prepared with PCR grade $\mathrm{H}_{2} \mathrm{O}$ $27.75 \mu 1$, reaction buffer $(10 \mathrm{X}) 5 \mu \mathrm{l}, \mathrm{MgCl}_{2}$

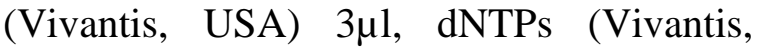
USA) $4 \mu 1$, Taq (Vivantis, USA) $0.5 \mu 1$, Forward and Reverse primer (Genelink, USA) $2.5 \mu \mathrm{l}$ each. The MG primers used in this study were consisted of the following sequences;

MG-25F: 5'-GGATCCCATCTCGACCACGAGAAAA-3' MG-25R: 3'-CCTTCAATCAGTGAGTAACTGATGA-5' $[8,22,23]$.

PCR master mix of $45 \mu 1$ was prepared from above composition and put into PCR tubes under a safety cabinet. A $5 \mu \mathrm{l}$ DNA (PCR 
amplicon was mixed into all PCR tubes. All tubes were placed in a PCR thermo-cycler (Applied Biosystems, USA) for the following cycles: 40 cycles: $94^{\circ} \mathrm{c}$ for 5 minutes, $94^{\circ} \mathrm{c}$ for 60 seconds, $55^{\circ} \mathrm{c}$ for 60 seconds, $72^{\circ} \mathrm{c}$ for 120 seconds, (final extension): $72^{\circ} \mathrm{c}$ for 7 minutes and soak at $4^{\circ} \mathrm{c}$. The amplified PCR product was exposed to agarose gel electrophoresis with $2 \%$ agarose, $1 \%$ TAE buffer and $0.5 \mu \mathrm{g} / \mathrm{mL}$ ethidium bromide. Each of the amplified products was loaded with $5 \mu \mathrm{L}$ in the individual wells of the gel. First and last well of every row was loaded with a DNA ladder of 100 bp (Vivantis, S., Coast
Highway Suite 1, Oceanside CA 92054, 1012, USA). The electric current of 100 volts was applied for $30 \mathrm{~min}$. The resulting bands were visualized under Ultra Violet trans-illuminator Dolphin-View (WEALTEC, USA) gel documentation system (WEALTEC, USA).

Results

SPA and ELISA Test

Mycoplasma gallisepticum antigen/antibody sense by SPA plus ELISA in layer blood samples $(\mathrm{N}=720)$ from sixty farms were $166 / 720 \quad(23 \%)$ and 238/720 (33\%) respectively (Table 1$)$.

Table 1. Detection of M. gallisepticum from serum samples by SPA and ELISA tests plus identification of field isolates from lung tissue cultures by PCR

\begin{tabular}{|l|l|l|l|l|l|}
\hline Flock type & Mycoplasma & $\begin{array}{l}\text { SPA test } \\
\mathbf{1}(\boldsymbol{\%})\end{array}$ & $\begin{array}{l}\text { ELISA test } \\
\mathbf{2}(\boldsymbol{\%})\end{array}$ & $\begin{array}{l}\text { Culture }^{\mathbf{3}} \\
(\boldsymbol{\%})\end{array}$ & PCR $^{\mathbf{4}(\%)}$ \\
\hline Layers & $\begin{array}{l}\text { Mycoplasma } \\
\text { gallisepticum }\end{array}$ & $166 / 720(23)$ & $238 / 720(33)$ & $\begin{array}{l}255 / 1112 \\
(23)\end{array}$ & $211 / 1112(19)$ \\
\hline
\end{tabular}

${ }^{1}$ Serum plate agglutination test

${ }^{2}$ Enzyme linked immunosorbent assay

${ }^{3}$ Isolate by culture from lung tissue

${ }^{4}$ Polymerase chain reaction test

\section{Bacterial processing}

Out of $(n=1560)$ lung tissue samples, isolates that were Digitonin sensitive were processed for bacteriological isolation of Mycoplasma.

\section{Polymerase chain reaction}

DNA from triple cloned Mycoplasma cultures were evaluated by specific Mycoplasma gallisepticum-PCR [8]. From Mycoplasma cultures, the PCR product was 730 bp. (Figure 1).

\section{Discussion}

The occurrence of Mycoplasma gallisepticum in sera of layer flock is awful. Sera screening by SPA and ELISA tests were helpful for an early diagnosis of respiratory symptoms in Mycoplasma gallisepticum suspected layers. Our investigation in relation to ELISA found more Mycoplasma gallisepticum positive samples (Table 1). A higher incidence of Mycoplasma gallisepticum by ELISA than SPA test was $23.33 \%$ and $33 \%$ respectively is in agreement with similar studies [21]. So, in this study the ELISA test was found more sensitive than SPA, which is in line with those reported by some earlier authors [14, 24]. Mycoplasma positive flocks in Pakistan are depopulated but the higher rate of Mycoplasma gallisepticum in Quetta layer flocks indicated that these farms are not adopting biosecurity and hygienic measures. It is suggested that SPA and ELISA should be carried out along with polymerase chain reaction for final confirmation of mycoplasma infections [14, 24].

Avian Mycoplasma identification by PCR in Balochistan has been reported here for the first time. This revision reassures the high frequency of Mycoplasma gallisepticum 
$(19 \%)$ in layers as previously presented in province of Punjab in Pakistan [14]. Previous studies have reported relatively higher percentage of prevalence of Mycoplasma gallisepticum [23]. Our lower occurrence may be due to variables related to degree of Mycoplasma gallisepticum illness or to sampling errors. Besides isolation, new techniques like serology and the molecular method (PCR) are also introduced in Balochistan to detect the presence of Mycoplasma gallisepticum causing respiratory problems in layers. Several researchers powerfully sustain the use of PCR very specific in Mycoplasma gallisepticum disease because PCR is very sensitive than serology and culture. It provides more reliable positive results than cultures. Despite, the fact that culture is difficult and more time consuming, it is somewhat helpful and may be used in parallel to PCR for more acceptability and conformity to diagnosis [15].

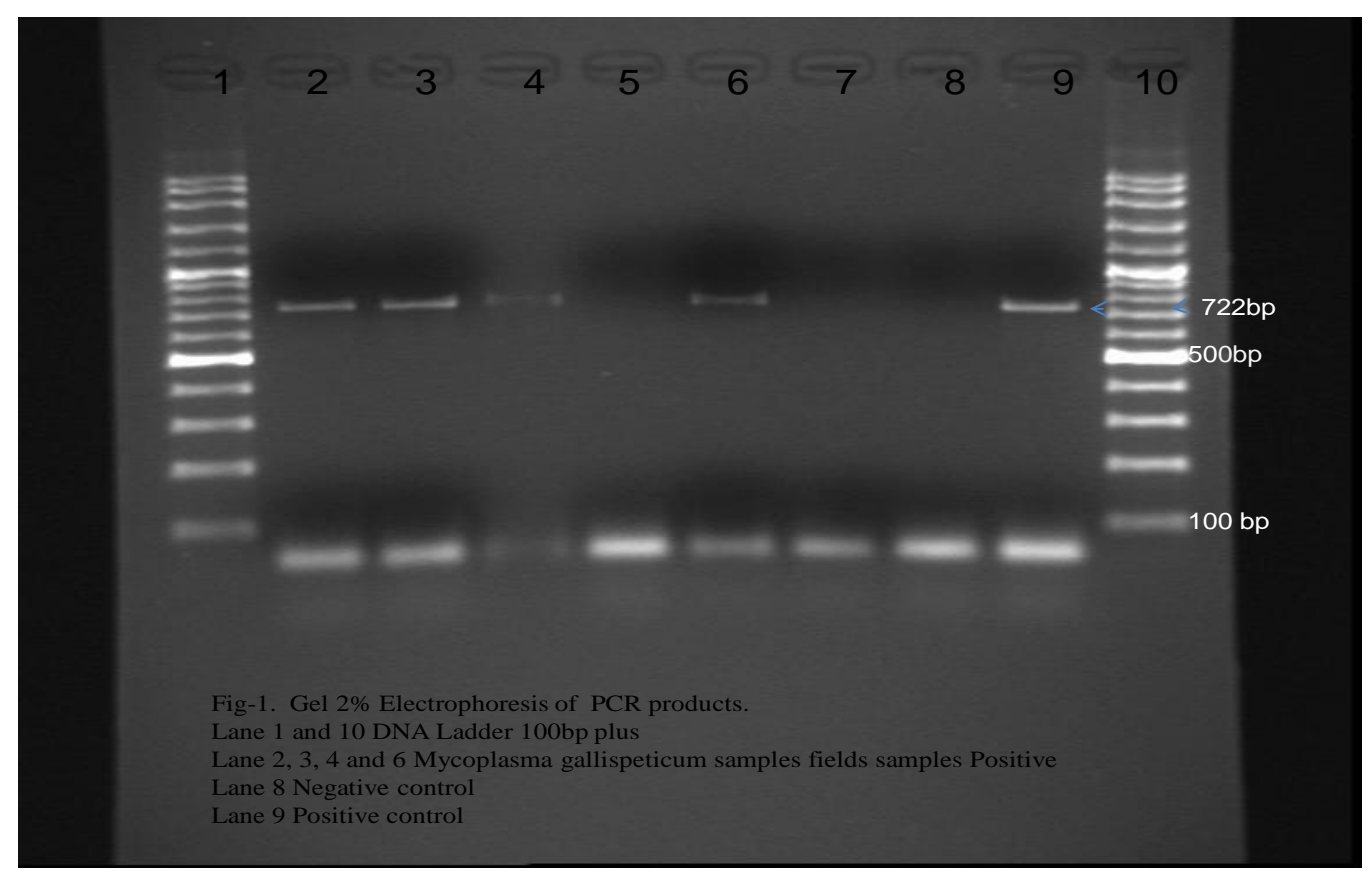

Figure 1. Gel 2\% electrophoresis of PCR products. Lane 1 and 10 DNA ladder 100bp phis, Lane 2, 3, 4 and 6 Mycoplasma gallispeticum samples field's samples positive, Lane 8 negative control, Lane 9 positive control

\section{Conclusions}

The losses to the commercial layers can be reduced through the routinely serological screening, quick decision of use of antibacterial cure and execution of firm biosecurity procedures. It can be recommended that poultry birds transported from other provinces for sale into Balochistan should be screened for Mycoplasma gallisepticum and
Mycoplasma synoviae using the SPA, ELISA plus PCR. Local flocks should be monitored for the Mycoplasma infections. Further studies of molecular methods (PCR) along with analysis of Mycoplasmas with suitable restriction endonucleases are required. Presence of Mycoplasma gallisepticum is very alarming situation for commercial poultry farmers in Balochistan. 


\section{Authors' contributions}

Conceived and designed the experiments: MA Atique, $F$ Abbas \& MA Awan, Performed the experiments: MA Atique \& S Babar, Analyzed the data: MM Tariq \& I Ali, Contributed reagents/ materials/ analysis tools: MM Tariq \& I Ali, Wrote the paper: MA Atique, MA Awan \& F Bokhari.

\section{References}

1. Fraga AP, Tatiana DV, Ikuta I, Fonseca ASK, Celmer AJ \& Lunge VR (2013). A Multiplex real-time PCR for detection of Mycoplasma gallisepticum and Mycoplasma synoviae in clinical samples from Brazilian commercial poultry flocks. Brazilian J Microbiol 44(2): 505-510

2. Razin S (2005). The genus Mycoplasma and related genera (class Mollicutes). In: Dworkin $\mathrm{M}$ et al. (eds) The Prokaryotes: An Evolving Electronic Resource for the Microbiological Community. 3rd ed. release 3.19. Springer-Verlag, New York.

3. Kleven SH \& Bradbury JM (2008). Avian Mycoplasmosis (Mycoplasma gallisepticum, M. synoviae). In: Manual of Diagnostic Tests and Vaccines for Terrestrial Animals. World Organization for Animal Health, Paris (6): 482-496.

4. Landman WJM \& Dutch D (2008). Mycoplasma synoviae field isolates originating from joint lesions and the respiratory tract of commercial poultry. Avian Pathol 37(4): 415-420.

5. Bradbury JM (2001). Avian mycoplasmosis. In Poultry diseases. Jordan F, Pattison MD, Alexander T, Faragher T, Saunders WB, New York (5): 178-193.

6. OIE Terrestrial Manual (2008). Avian mycoplasmosis, Mycoplasma gallisepticum, M. Synoviae: 484-485

7. Piscopo MV, Unzaga F, Marrio F \& Petrucceli MA (2011). Presence of
Mycoplasma gallisepticum and Mycoplasma sinoviae in a case of infectious sinusitis in Turkeys: xxii Latin Am Poult Cong.

8. Nascimento ER, Yamamoto R, Herrick KR \& Tait RC (1991). Polymerase chain reaction for detection of Mycoplasma gallisepticum. Avian Dis 35: 62-69.

9. Yilmaz F, Timurkaan N, Kilic A, Kalender H \& Kilinc U (2011). Detection of Mycoplasma synoviae and Mycoplasma gallisepticum in chickens by immunohistochemical, PCR and culture methods. Rev Med Vet 62(2): 79-86

10. Hassan S, Mukhtar NSU, Rahman AA \& Mian AA (2014). Molecular epidemiology of Mycoplasma gallisepticum in different types of chickens. Int J Agri Biol 16: 165-170.

11. Ley DH (2003). Mycoplasma gallisepticum Infection. In: YMHJ. Saif JR, Barnes AM, Glisson LR, Fadly LR, McDougald \& Swayne DE (Eds.). Diseases of Poultry. Eleventh ed. Ames. Iowa, Iowa State Press, A Blackwell Publishing Company, USA: 722-744.

12. Ley DH \& Yoder JHW (1997). Mycoplasma gallisepticum infection. In Calnek BW, Barnes HJ, Beard CW, L.R. McDougal LR \& Saif YM (ed.) Diseases of poultry, 10th ed. Iowa State University Press, Ames: 194-207.

13. Prodhan MAM (2002). Studies on avian Mycoplasmosis: Prevalence, Isolation, Characterization and Antigenic properties. A PhD thesis offered from Department of Rapid Slide Agglutination and Polymerase Chain Reaction for Detection of Mycoplasma gallisepticum in Breeder Flocks. Pakistan j life soc science (1-2): 1-5.

14. Kleven S (1998). Mycoplasmas in the etiology of multifactorial respiratory 
disease. Poult Science 77(8): 11461149.

15. Abdelmoumen BM, Ben Mohamed R, Gueriri L, Boughattas S \& Mlik B (2005). Duplex PCR to differentiate between Mycoplasma synoviae and Mycoplasma gallisepticum on the basis of conserved species-specific sequences of their hemagglutinin genes. J Clin Microbiol 43: 948-958.

16. Lauerman, LH, Hoerr FJ, Shapton AR, Shah SM \& Saten VL (1993). Developement and application of a Polymerase Chain reaction Assay for Mycoplasma synoviae. Avian Dis 37: 829-834.

17. Ferguson NM, Hepp DD, Sun S, Ikuta N, Levisohn S, Kleven SH, \& Garcia M (2005). Use of molecular diversity of Mycoplasma gallisepticum by genetargeted sequencing (GTS) and random amplified polymorphic DNA (RAPD) analysis for epidemiological studies. $M$ Biol 151: 1883-1893

18. Nascimento ER, Nascimento MGF, Danelli MGM, Machado SL, Lignon GB, Polo PA (1998). Comparison of PCR kits for the detection of Mycoplasma gallisepticum and $M$. synoviae (MS) in MS infected and uninfected chickens. In: Proceedings of the $47^{\circ}$ Western Poultry Disease Conference. Sacramento, California, USA: 84-86.
19. Osman KM, Aly ZM, Amin MM \& Hasan BS (2009). Mycoplasma gallisepticum: an emerging challenge to the poultry industry in Egypt. Rev Science Tech 28: 1015-1023

20. Jalal SM, Pourbaksh SA \& Kheirkhah B (2014). Isolation and Identification of Mycoplasma gallisepticum in chickens form industrial farms in Kerman province. Int J of Adv Biol Biomed Res 2(1): 100-104

21. Atif H \& Najeeb MI (2007). Comparison of Conventional Bacterial isolation, Rapid Slide Agglutination and Polymerase Chain Reaction for Detection of Mycoplasma gallisepticum in Breeder Flocks. Pakistan J Life Soc Science 1(2): 1-5

22. Frey ML, Hanson RP, \& Anderson DP (1968). A medium for the isolation of avian Mycoplasmas. American $\mathrm{J}$ Vet Res 29: 2163-2171

23. Gharaibeh S \& Roussan DA (2008). The use of Molecular techniques in isolation and characterization of Mycoplasma gallisepticum from commercial chickens in Jordan. Int $J$ of Poult Science 7(1): 28-35.

24. Feizi A, Bijanzad P, Khakpour M, Nikpiran H, Kaboli K, \& Moggadam ARJ (2013). Seroprevalence of Mycoplasma gallisepticum infection in Iranian north-west broiler breeder farms. Annals of Biol Res 4(4): 109-111. 